\title{
Changed species composition of naked amoebae in soils of forest-and-steppe zone of Ukraine
}

\author{
MARINA PATSYUK \\ Zhytomyr Ivan Franko State University, Vel. Berdychivska st., 40, Zhytomyr, 10008 Ukraine \\ Corresponding author, e-mail: kostivna@ukr.net
}

Keywords naked amoebae, morphotypes, soils, forest-and-steppe, Ukraine

Abstract Twenty-three species of naked amoebae of 3 classes, 11 families and 16 genera were found in soils of the forest-and-steppe zone of Ukraine. The most common species were Vahlkampfia sp. (2), Vahlkampfia sp. (1), D. mycophaga, H. vermiformis, T. striata, R. platypodia, M. cantabrigiensis, Vexillifera sp., Cochliopodium sp. (1), Acanthamoeba sp. (1). The species with least occurrence were Polychaos sp., T. similis, T. terricola, M. viridis, Rhizamoeba sp. (1). Highest species diversity of naked amoebae was recorded for soils of forests and shrubs, least for soils of meadows. All of the found amoebae species belong to 12 morphotypes.

\section{Zmiany składu gatunkowego ameb nagich w glebie w gradiencie siedlisk stepowych i leśnych}

Słowa kluczowe ameby nagie, morfotypy, gleba, gradient step-las, Ukraina

Streszczenie Dwadzieścia trzy gatunki nagich ameb z 3 klas, 11 rodzin i 16 rodzajów znaleziono w glebach strefy leśno-stepowej Ukrainy. Najczęściej występującymi gatunkami były Vahlkampfia sp. (2), Vahlkampfia sp. (1), D. mycophaga, H. vermiformis, T. striata, R. platypodia, M. cantabrigiensis, Vexillifera sp., Cochliopodium sp. (1), Acanthamoeba sp. (1). Najwyższą różnorodność gatunkową nagich ameb odnotowano dla gleb lasów i krzewów, najmniejszą - dla gleb łąk. Wszystkie znalezione gatunki ameb należą do 12 morfotypów.

\section{Introduction}

The forest-and-steppe zone is the transitional area between the forest and steppe biocoenoses. The corresponding changes in composition structure of soil fauna can be easily observed there. According to current studies, there are both truly forest soils (gray and gray forest soils) and steppe soils (typical chernozems). Podzolic soils (dark gray podzols and podzolic chernozems), which form under forest and steppe biocoenoses, are a special case. In the forest-and-steppe zone, three provinces (Polisko-Prydnistrovskyi, Livoberezhno-Dnistrovskyi and Skhidno-Ukrainskyi) are recognized (Pankiv, 2017). 
Naked amoebae are the usual components of soil, freshwater and seawater faunas. In Ukraine, these protists have been studied only in fresh waters (Patsyuk, Dovgal, 2012; Patsyuk, 2014, 2016a, 2018a). Our work aimed to analyze the changes in species composition of amoebae in soils of forest-and-steppe biocoenoses of Ukraine.

\section{Materials and methods}

Sampling was conducted in 2018-2019, and altogether 138 samples were collected in 12 locations (Figure 1). Soil cuts for protozoological analysis were established at study areas. Samples were taken from the surface soil horizon $(0-5 \mathrm{~cm})$. On each area, three pairs of samples were taken.

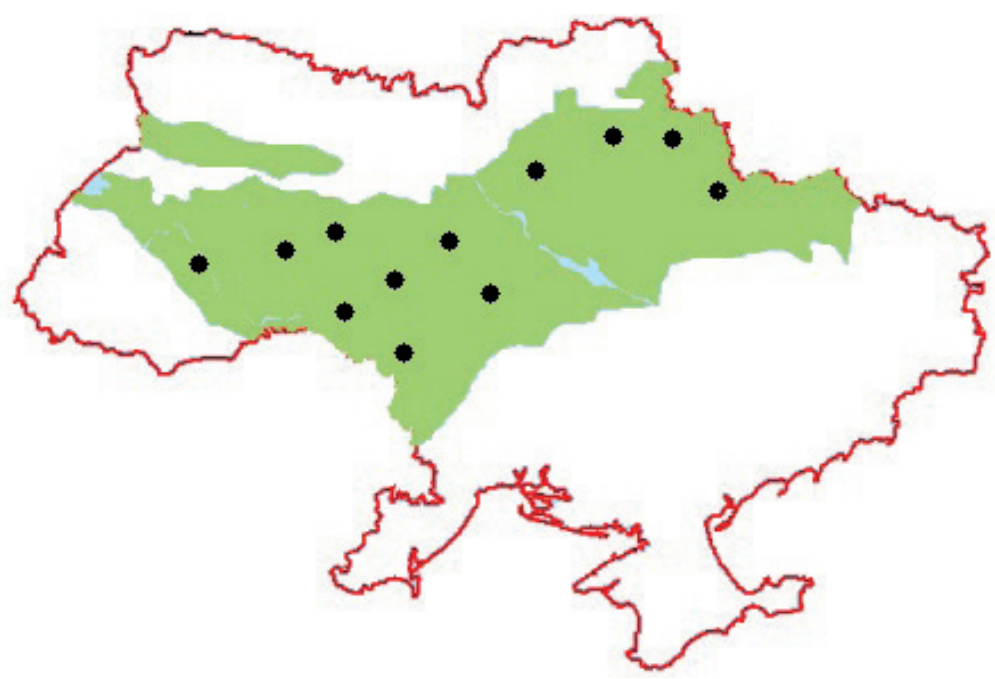

Figure 1. Sampling locations (Ukraine)

Soil cover was represented by chernozems characterized as intermediate between the dark gray forest soils to podzolic chernozems.

Soil acidity was measured with laboratory $\mathrm{pH}$-meter 150-M. The soil reaction varied from weakly acid (6.3) to neutral (7.2).

Soil temperature was determined on the depth of down to $5 \mathrm{~cm}$ using soil thermometer. Samples was mostly taken during warm season, temperature of studied soils was in average $+17^{\circ} \mathrm{C}$.

The amoebae were multiplied and maintained according to Page (1991) in laboratory conditions at $+20^{\circ} \mathrm{C}$.

Our data are insufficient to make any conclusions about the abundance of amoebae, thus we analyzed the frequency of finding the protists in soils of the forest-and-steppe zone of Ukraine.

Cluster analysis was used to classify the protist communities. All calculations were conducted using the software program packet Past 1.18 (Hammer et al., 2001). 


\section{Results and discussion}

The species composition of naked amoebae was studied in soils of the forest-and-steppe zone of Ukraine on 12 study plots. The plots were chosen to be comparatively distant from each other and with various plant associations of the forest-and-steppe ecotone, showing different stages of over-forestation of steppe (Mazei, Embulayeva, Trulova, 2013).

Four plots were chosen at meadow steppe areas. The most common plant species included Elytrigia repens, Acuillea nobilis, Eringium campestre, Artemisia absinthium, Plantago major, Hieracium piloselioides, Artemisia absinthium, Agrimonia eupaforia, Berteroa incana, Polygonatum officinale etc.

Four other plots were chosen under shrubs. The most prevalent plant species were Urtica dioisa, Sambucus nigra, Sorbus aucuparia, etc.

And finally, four plots were established in forest areas. The most common trees were Quercus robur, Carpinus betulus, Betula pendula, Pinus sylvestris, Corylus avellana, Tilia cordata and other species.

In the studied soils, 23 species of naked amoebae were found. These are listed below, according to the system in (Smirnov, Chao, Nassonova, Cavalier-Smith, 2011; Bass et al., 2009).

Class Tubulinea Smirnov et al., 2005

Order Tubulinida Smirnov et al., 2005

Family Amoebidae Ehrenberg, 1838

Genus Polychaos Schaeffer, 1926

Polychaos sp.

Genus Deuteramoeba Page, 1987

Deuteramoeba mycophaga Page, 1988

Family Hartmannellidae (Volkonsky, 1931) Page, 1974

Genus Saccamoeba Frenzel, 1892

Saccamoeba stagnicola Page, 1974

Genus Hartmannella Page, 1974

Hartmannella vermiformis Page, 1967

Genus Cashia Page, 1974

Cashia limacoides Page, 1974

Order Leptomyxida Pussard et Pons, 1976

Family Leptomyxidae Pussard et Pons, 1976

Genus Rhizamoeba Page, 1972

Rhizamoeba sp. (1)

Class Discosea Cavalier-Smith et al., 2004

Subclass Flabellinia Smirnov et al., 2005

Order Dactylopodida Smirnov et al., 2005

Family Paramoebidae Poche, 1913

Genus Korotnevella Page, 1981

Korotnevella sp. (1)

Family Vexilliferidae Page, 1987

Genus Vexillifera Schaeffer, 1926

Vexillifera sp. 
Order Vannellida Smirnov et al., 2005

Family Vannellidae Bovee, 1970

Vannella sp.

Genus Ripella Smirnov, Nassonova, Chao et Cavalier-Smith, 2007

Ripella platypodia Smirnov, Nassonova, Chao et Cavalier-Smith, 2007

Order Himatismenida Page, 1987

Suborder Tectiferina Smirnov, Nassonova, Chao et Cavalier-Smith, 2011

Family Cochliopodiidae De Saedeleer, 1934

Genus Cochliopodium Hertwig et Lesser, 1874

Cochliopodium sp. (1)

Subclass Longamoebia Smirnov, Nassonova, Chao et Cavalier-Smith, 2011

Order Dermamoebida Cavalier-Smith et al., 2004

Family Mayorellidae Schaeffer, 1926

Genus Mayorella Schaeffer, 1926

Mayorella viridis Leidy, 1874

Mayorella cantabrigiensis Page, 1983

Mayorella sp.

Order Thecamoebida Smirnov, Nassonova, Chao et Cavalier-Smith, 2011

Family Thecamoebidae Schaeffer, 1926

Genus Thecamoeba Fromentel, 1874

Thecamoeba striata Penard, 1890

Thecamoeba terricola (Greef, 1866) Lepsi, 1960

Thecamoeba similis Lepsi, 1960

Genus Stenamoeba Smirnov et al., 2007

Stenamoeba stenopodia (Page, 1969) Smirnov et al., 2007

Order Centramoebida Rogerson and Patterson, 2002

Family Acanthamoebidae Sawyer and Griffin, 1975

Genus Acanthamoeba Volkonsky, 1931

Acanthamoeba sp. (1)

\section{Class Heterolobosea Page et Blanton, 1985}

Family Vahlkampfiidae Jollos, 1917

Genus Vahlkampfia Chatton et Lalung-Bonnaire, 1912

Vahlkampfia sp. (1)

Vahlkampfia sp. (2)

Genus Willaertia De Jonckheere, Dive, Pussard et Vickerman, 1984

Willaertia sp.

Genus Naegleria Alexeieff, 1912

Naegleria gruberi Schardinger, 1899

The most common species was Vahlkampfia sp. (2). It was also one of the dominant species in almost all local communities (Table 1). Vahlkampfia sp. (1), D. mycophaga, H. vermiformis, T. striata, R. platypodia, M. cantabrigiensis, Vexillifera sp., Cochliopodium sp. (1), Acanthamoeba sp. (1) (in total, $43.5 \%$ of all found species) were present in more than in $50 \%$ of biotopes. The representatives of class Disciosea were more prevalent (13 species, $56.52 \%$ of all 
identified species). Class Tubulinea was represented by six species $(26.08 \%)$, and four species of class Heterolobosea were found (17.39\%) (Figure 2).

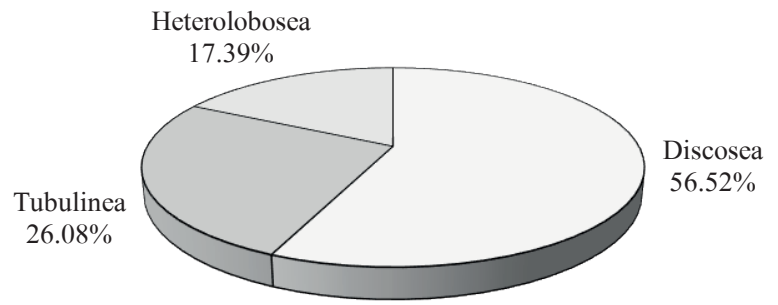

Figure 2. Distribution of naked amoebae in soils of forest-and-steppe zone of Ukraine

By the species structure, the amoebae communities varied (Figure 3). The most specific communities were formed under shrub phytocoenoses. In those, the most frequent species were Vahlkampfia sp. (2), C. limacoides, and Mayorella sp. In all other biotopes, the most frequent species were Vahlkampfia sp. (1), H. vermiformis, Vannella sp., Vexillifera sp., Cochliopodium sp. (1), and Acanthamoeba sp. (1). The frequency of finding those species in samples was higher than $65 \%$, and they made up $26 \%$ of all identified species. All of the most frequently found amoebae were the core of communities in several biotopes, determining the biocoenotic similarity of protists. However, the list of most common species was different in each community. Thus the variability of communities was shaped by recombining a small number of species.

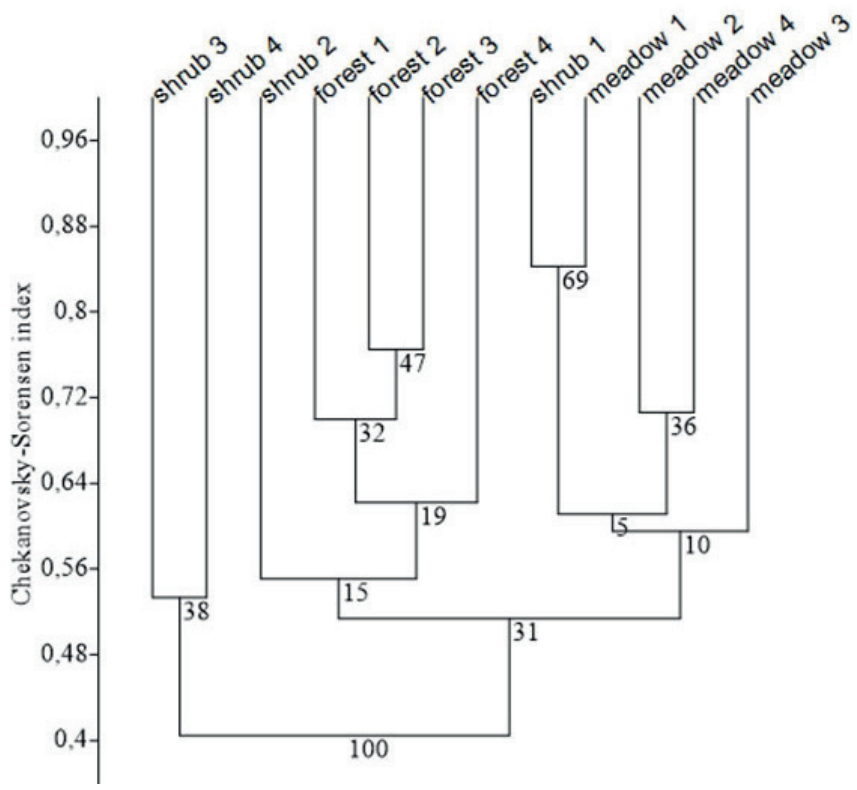

Figure 3. Results of classification of naked amoebae communities from different biotopes by the species composition (nodes of the dendrogram show support values in percent, bootstrap 1,000) 
By the species composition (Figure 4) the protist communities divided into two groups: from forest phytocoenoses, and from steppe and shrub biocoenoses. Five of the 23 found species were not found in soils of meadows and shrubs (Polychaos sp., M. viridis, T. terricola, T. similis, Korotnevella sp. (1)), four species were absent in meadow soils (D. mycophaga, S. stagnicola, C. limacoides, Willaertia sp.), one species in soils under shrubs (Rhizamoeba sp. (1)), one species was not found in soils of meadows and forests (Mayorella sp.) (Table 1).

Table 1. Species composition of naked amoebae in community

\begin{tabular}{|c|c|c|c|c|c|c|c|c|c|c|c|c|c|}
\hline \multirow[b]{2}{*}{ No. } & \multirow[b]{2}{*}{ Taxon } & \multicolumn{12}{|c|}{ Biotope } \\
\hline & & 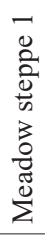 & 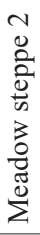 & 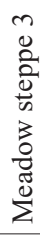 & 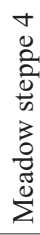 & & 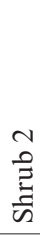 & 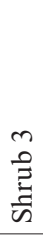 & 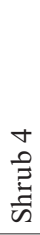 & $\begin{array}{l}\overrightarrow{\tilde{D}} \\
\mathbb{0} \\
\dot{0} \\
0\end{array}$ & 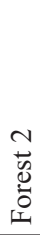 & 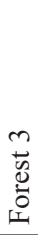 & 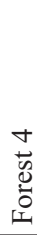 \\
\hline 1. & Vahlkampfia sp. (1) & + & + & + & + & + & + & - & - & + & + & - & + \\
\hline 2. & Vahlkampfia sp. (2) & + & + & + & + & + & + & + & + & + & + & + & + \\
\hline 3. & N. gruberi & - & - & + & - & - & + & + & - & + & - & - & - \\
\hline 4. & Willaertia sp. & - & - & - & - & - & - & + & - & - & + & + & - \\
\hline 5. & Polychaos sp. & - & - & - & - & - & - & - & - & - & + & - & + \\
\hline 6. & D. mycophaga & - & - & - & - & - & + & + & - & + & + & + & + \\
\hline 7. & S. stagnicola & - & - & - & - & - & + & - & - & + & + & + & + \\
\hline 8. & H. vermiformis & + & + & + & + & + & - & - & + & - & - & + & + \\
\hline 9. & C. limacoides & - & - & - & - & + & + & + & + & - & + & - & - \\
\hline 10. & Rhizamoeba sp. (1) & - & - & - & + & - & - & - & - & + & + & + & - \\
\hline 11. & Korotnevella sp. (1) & - & - & - & - & - & - & - & - & + & + & + & + \\
\hline 12. & Vexillifera sp. & + & - & + & + & + & - & - & + & + & + & + & - \\
\hline 13. & Vannella sp. & - & + & + & + & - & + & - & - & + & + & + & + \\
\hline 14. & R. platypodia & - & + & - & + & + & - & + & - & - & + & + & + \\
\hline 15. & Cochliopodium sp. (1) & + & - & + & - & + & + & - & - & + & + & + & - \\
\hline 16. & M. viridis & - & - & - & - & - & - & - & - & - & - & + & - \\
\hline 17. & M. cantabrigiensis & + & + & - & - & + & - & + & - & - & + & + & + \\
\hline 18. & Mayorella sp. & - & - & - & - & + & + & + & + & - & - & - & - \\
\hline 19. & T. striata & - & + & - & + & - & - & + & + & + & + & + & - \\
\hline 20. & T. terricola & - & - & - & - & - & - & - & - & - & + & + & - \\
\hline 21. & T. similis & - & - & - & - & - & - & - & - & + & - & + & - \\
\hline 22. & S. stenopodia & + & + & - & - & + & + & - & - & - & + & - & - \\
\hline 23. & Acanthamoeba sp. (1) & + & - & - & + & + & + & - & - & + & + & - & + \\
\hline \multirow{2}{*}{\multicolumn{2}{|c|}{ Total }} & 8 & 8 & 7 & 9 & 11 & 11 & 9 & 6 & 13 & 18 & 16 & 11 \\
\hline & & \multicolumn{4}{|c|}{13} & \multicolumn{4}{|c|}{17} & \multicolumn{4}{|c|}{22} \\
\hline
\end{tabular}

In soils under shrubs, Vahlkampfia sp. (2), C. limacoides, and Mayorella sp. were the most common taxa, making up $17.6 \%$ of all identified species; the least common were Willaertia sp., S. stagnicola, Vannella sp. (17.6\% of all noted species). Vahlkampfia sp. (1), N. gruberi, D. mycophaga, $H$. vermiformis, $T$. striata, $R$. platypodia, S. stenopodia, M. cantabrigiensis, Vexillifera 
sp., Cochliopodium sp. (1), and Acanthamoeba sp. (1) were recorded with the average frequency (64\% of all amoeba found in soils under shrubs).

In forest phytocoenoses, the most characteristic species were Vahlkampfia sp. (2), D. mycophaga, S. stagnicola, Vannella sp., and Korotnevella sp. (1) (23\% of all found species). Four (18\%) of 22 amoeba species were the least common: $N$. gruberi, C. limacoides, S. stenopodia, $M$. viridis. Finally, Vahlkampfia sp. (1), Polychaos sp., H. vermiformis, T. striata, T. terricola, T. similis, R. platypodia, M. cantabrigiensis, Vexillifera sp., Rhizamoeba sp., Cochliopodium sp. (1), and Acanthamoeba sp. (1) that made up 59\% of all found amoebas, were found with average frequency.

It should be noted that most of the identified species can be considered eurybiont because they can be found both in soils and in aquatic biotopes (Patsyuk, Dovgal, 2012; Patsyuk, 2014, 2016a, b, 2018a, b).

It should be noted that the least numerous species in soils of the forest-and-steppe biocoenoses of Ukraine were Polychaos sp. (15\%), T. similis (5\%), T. terricola (7.5\%), M. viridis (0.8\%), and Rhizamoeba sp. (1) (12\%).

In soils of the forest-and-steppe biogeocoenoses of Ukraine, we found amoebae of 12 morphotypes: eruptive (Vahlkampfia sp. (1), Vahlkampfia sp. (2), N. gruberi, Willaertia sp.), polytactic (Polychaos sp., D. mycophaga), monotactic (S. stagnicola, H. vermiformis, C. limacoides), lens-like (Cochliopodium sp. (1)), striate (T. striata, T. similis), rugose (T. terricola), fan-shaped (Vannella sp., R. platypodia), mayorellian (M. viridis, M. cantabrigiensis, Mayorella sp.), dactylopodial (Korotnevella sp. (1), Vexillifera sp.), acanthopodial (Acanthamoeba sp. (1)), branched (Rhizamoeba sp. (1)), and lingulate (S. stenopodia). Amoebae of all morphotypes were recorded in forest soils, and of 10 morphotypes in meadow soils and under shrubs (where amoebae of polytactic and rugose, and of rugose and branched morphotypes were absent, respectively). In more than half studied biotopes we have found species of eruptive, polytactic, monotactic, mayorellian, dactylopodial, lens-like, striate, lanceolate, fan-shaped, and acanthopodial morphotypes, which is two thirds of all known morphotypes.

Thus, we've identified 23 species of naked amoebae of 12 morphotypes in soils of the forestand-steppe zone of Ukraine. The highest number of species was characteristic of forest soils (22 species) and soils under shrubs (17 species), which are $96 \%$ and $74 \%$ of all identified species. The lowest number of species was found in meadow soils (13 species, $56 \%$ of all found species). Possibly, the high diversity of amoebae in soils of forests and under shrubs of the forest-and-steppe zone of Ukraine strongly depends on the humidity and type of soil, a hypothesis which will be tested in detail in our further studies.

\section{References}

Bass, D., Chao, E., Nikolaev, S., Yabuki, A., Ishida, K., Berney, C., Pakzad, U., Wylezich, C., Cavalier-Smith, T. (2009). Phylogeny of Novel Naked Filose and Reticulose Cercozoa: Granofilosea cl. n. and Proteomyxidea Revised. Protist, 160, 75-109.

Hammer, Ø., Harper, D.A.T., Ryan, P.D. (2001). PAST: Palaeontological statistics software package for education and data analysis. Palaeontol. electronica, 4 (1), 1-9.

Mazei, Yu., Embulayeva, E., Trulova, A. (2013). Terricolous testate amoebae in forest-steppe ecosystems (on the data of natural reserve «Volga region forest-steppe»). University Proceedings Volga Region, Natural Sciences, 2 (2), 5-26 [in Russian].

Page, F.C., Siemensma, F.J. (1991). Nackte Rhizopoda und Heliozoea (Protozoenfauna Band 2). StuttgartNew York: Gustav Fischer Verlag. 
Pankiv, Z.P. (2017). Soils of Ukraine: a study book. Lviv, Ivan Franko State University, 112 [in Ukraine].

Patcyuk, M.K., Dovgal, I.V. (2012). Biotopic distribution of naked amoebes (Protista) in Ukrainian Polissya area. Vestnik zoologii, 46 (4), 355-360.

Patsyuk, M.K. (2014). Morphotypes in Naked Amoebas (Protista): Distribution in Water Bodies of Zhytomyr and Volyn Polissia (Ukraine) and Possible Ecological Significance. Vestnik zoologii, 48 (6), $547-552$.

Patsyuk, M.K. (2016a). Seasonal changes in the species composition of naked amoebas (Amoebina) of the Teterev river (the Town of Zhitomir). Hydrobiological Jornal, 52 (4), 55-62.

Patsyuk, M.K. (2016b). New Finds of Naked Amoebae (Protista) in Water Reservoirs of Ukraine. Vestnik zoologii, 50 (4), 291-300.

Patsyuk, M.K. (2018a). Peculiarities of the Spatial Distribution of Naked Amoebas in Sandy Bottom Sediments of a Small River. Hydrobiological Jornal, 54 (5), 102-111.

Patsyuk, M. (2018b). Species Composition And Distribution Of Naked Amoebae In The Water Bodies of Lviv Region. Visnyk of the Lviv University, Series Biology, 79, 141-149.

Smirnov, A., Chao, E., Nassonova, E., Cavalier-Smith, T. (2011). A Revised Classification of Naked Lobose Amoebae (Amoebozoa: Lobosa). Protist, 162, 545-570.

Cite as: Patsyuk, M. (2019). Changed species composition of naked amoebae in soils of forest-and-steppe zone of Ukraine. Acta Biologica, 26, 57-64. DOI: 10.18276/ab.2019.26-06. 